\title{
Assessment of the Metering and Billing Systems of Water Supply in Some Parts of Osogbo Metropolis, Osun State Nigeria Fadipe, O.O., Thanni, M.O. and Adeyanju, M.I.
}

\begin{abstract}
This study assessed the water metering and billing methods in some parts of Osogbo metropolis of Osun State, Nigeria by evaluating the adequacy, effectiveness and cost implications of the systems. Data was obtained through a questionnaire survey, field observations and oral interviews. A total number of 200 questionnaires were randomly distributed to the households around the metered neighbourhood, 173 responses were retrieved for analysis. It was discovered that the waterworks only have a metering system for 3222 (0.85\%) households. It charges a fixed price of $\$ 2000 /$ month for those without water meters and $\$ 2700 /$ month for metered households. The percentages of domestic, industrial, religious, governmental and institutional water users were $41.6 \%, 30.6 \%, 8.7 \%, 8.1 \%$ and $11.0 \%$ respectively and a majority of the water users agreed to be consuming between $75-100$ litres of water per day. Considering the number of days that households get water, the study found that in a week, $16.8 \%, 46.8 \%$ and $36.4 \%$ of the respondents get water for, $1-2,2-4$, and $4-7$ days respectively. The study revealed that $9.8 \%, 23.1 \%, 48.6 \%$ and $18.5 \%$ of the respondents were $5-20 \%, 21-40 \%, 41$ $60 \%$ and $61-80 \%$ satisfied with their billing methods respectively. If water is available all the days of the week, the study found the billing system to be fair. Residents are then advised to subscribe to the metering and billing systems for fair bargaining.
\end{abstract}

Keywords: Metering, Billing, Cost analysis, Water demand, Add one more Keyword

\section{Introduction}

The economic development and human welfare of any nation depend on water, thus, management of water resources is crucial to the reduction of poverty and growth of the economy. Water is very vital to health but there is a shift in approach and principle in Nigeria to the management of this resource. Water is now recognized as a commodity of strategic importance because of demands, the rising cost of production and the diminishing supply. It is not feasible in a long-term, cost-effective and environmentally friendly manner to increase the quantity of water supply by building more dams, sinking more boreholes and building more conveyance systems; solutions must be

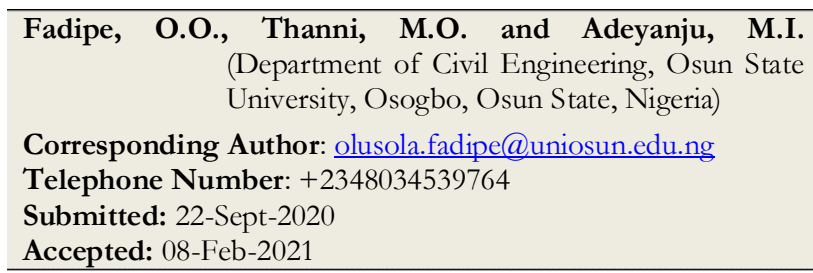

proffered at the user- end of the pipe [1].

The supply of water to rural and urban areas in Nigeria is mainly the responsibility of the state government, to own and maintain water supply infrastructure. Strategic management and provision of sustainable public water supply are essential for the future of the world's economy, industrial development, protection and improvement of public health [2-6]. Around the world, about 663 million people lack access to potable water and Sub-Sahara Africa has the largest population of people without access to potable water [7]. The objective of water supply is the provision of potable water on a regular basis which upholds security of supply across seasons, and it is also imperative if health and wider poverty mitigation benefits are to be met and sustained [8-10].

Water meters are being globally used to measure the volume of water supply and to monitor the use of water. Metering allow for fair pricing and control of service quality. The good thing about the metering system is that it 
protects the interest of customers, as they will be aware of how much the government charged per cubic meter. When the amount of water being supplied is metered and recorded, suppliers can then adjust operations to meet demand and adjust the price accordingly. In 2017, Lagos State provided 32,000 prepaid water meters to households as part of measures to ensure accurate billing for water consumption. It charged $\$ 200 / \mathrm{m}^{3}$ for lowdensity area, $260 / \mathrm{m}^{3}$ for high-density area and $¥ 350 / \mathrm{m}^{3}$ for commercial users [11].

Ede dam is responsible for ensuring the delivery of potable water to many cities in Osun State including the state capital, Osogbo. There are two supply systems to Osogbo; the first is directly from Ede dam and the second is from the reservoir (which receives treated water from Ede dam) in Osogbo. Most residents of Osogbo are not connected to the main water supply and are not aware of any water metering and the billing system [19]. Thus, it becomes imperative to assess the water supply procedures of the city, by evaluating the quantity of water demand of different consumers, assess the awareness and effectiveness of the water metering and billing systems and the cost implications of the piped water supply.

\section{Methodology \\ A. Study Area}

This research was carried out in some parts of Osogbo metropolis, the capital of Osun State, South-West, Nigeria. The city became the capital of Osun State in 1991. It has two local government areas (LGA); Osogbo and Olorunda LGAs. It is geographically located on latitudes $7^{\circ} 46^{\prime}$ North and longitudes $4^{\circ} 34^{\prime} \mathrm{E}$ with a total landmass of $2875 \mathrm{~km}^{2}$ [12]. The city has a population of 156,694 people according to 2006 census, and it increased to 499,999 in
2013 [12].The location of the study area on a map is shown in Figure 1.

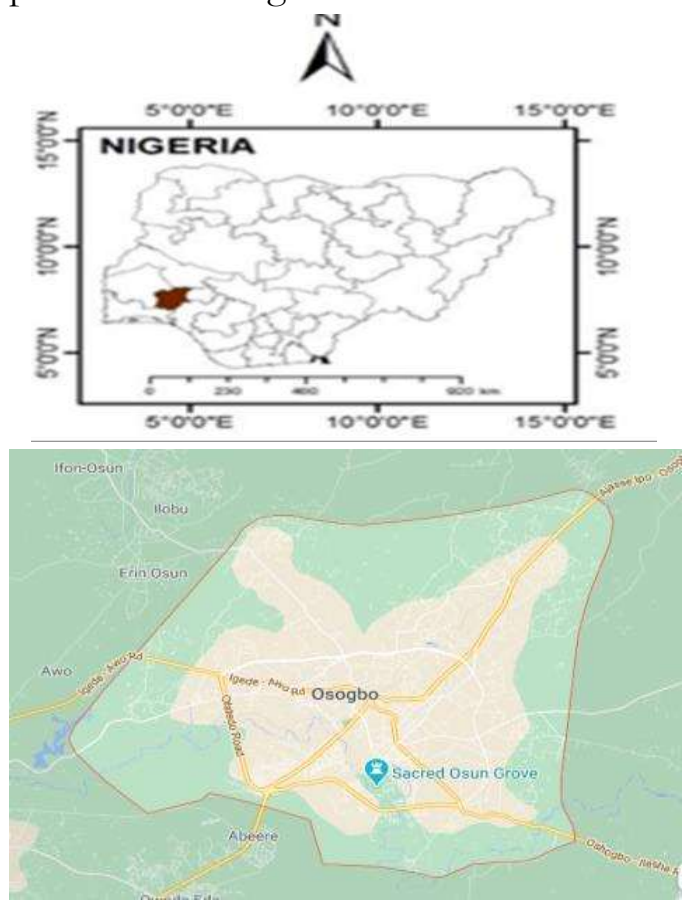

Figure 1: Map of Nigeria showing Osun State and Osogbo

\section{B. Questionnaires and Field study}

The data used in this study was obtained through a questionnaire survey, field observation, and oral interviews conducted in April 2017. A well -structured questionnaire was randomly administered to some households in the study area. Water consumers were stratified into streets and questionnaires were administered in a random manner. A total of 200 questionnaires were administered to residents of households and responses were retrieved for analysis. The questionnaires administered were divided into two parts. The first part contains the consumer's information and the second part contains the questions on metering, use of water and methods of billing. Oral interviews with Ede Water Works and Osun State Water Corporation personnel was used to collect information on the type of consumers, bill rates, number of metered households and cost implications of water treatment and supply. The recovered responses 
were then analyzed using the Statistical Package for the Social Sciences (SPSS).

\section{Results and Discussion}

There are five different types of consumers (Figure 2) from the result of the study. The percentage distribution are $41.6 \%, 30.6 \%$, $8.7 \%, 8.1 \%$ and $11.0 \%$ for domestic, industrial, religious, governmental and institutional water users respectively. This agrees with most studies on water supply [13] [14]. The rate of consumption by the consumers are 25-50 litres, 50-75 litres, 75-100 litres and 100 -175 litres (Figure 2). For domestic users, 9.7\% use between 25-50 litres/day, while $56 \%$ use between 100-175 litres/day. The first range of 25-50 litres/day is lower than the World Bank and WHO recommended water need (80lcpd and 100 lcpd respectively) for developing nations on daily basis; some of the respondents have a low level of education and this might have contributed to the low level of water use. The highest water use on daily basis is in the range of 75-100 litres/day for all the different types of consumers; it almost agrees with values of [15] and [16] for national standard residential water demand for urban areas. The active billed households in Osogbo are 3,222. The community with the highest number (889) of billed households is Dada Estate (Figure 3) while the least (64) is in Ogo-Oluwa community [19].

From Figure 4, it is evident that most households do not get water on a regular basis from the Water Works; $16.8 \%$ receive water between 1- 2 days (Figure 4), 48.6\% receive water between 2 - 4 days while $36.4 \%$ get water four to seven days in a week.

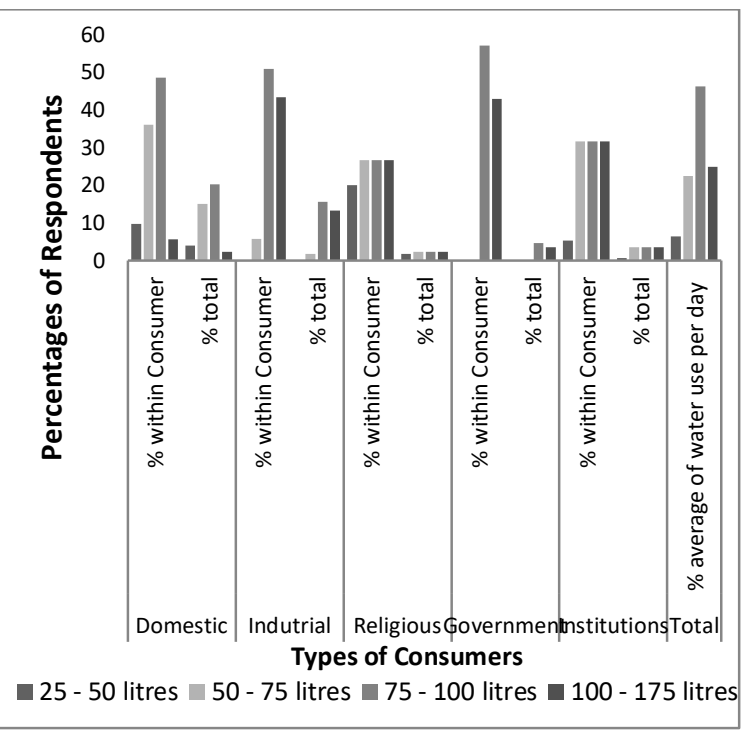

Figure 2: Types of consumers and their respective average quantity of water use per day

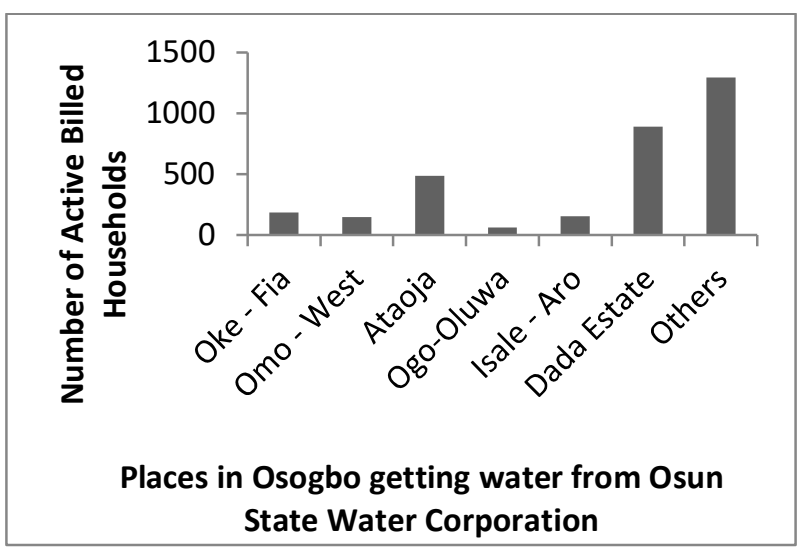

Figure 3: Summary of active billed households in Osogbo

The consumers that get water almost every day are those receiving water directly from Ede waterworks while those that have interrupted water supply are those that get water from the reservoir in Osogbo. The percentages of metered households are 50.3\% (Table 1) while $49.7 \%$ are not metered (flat rate billing). All the industrial, institutional and religious organizations that receive water are metered. The level of satisfaction with the metering and billing system are presented in Table 2. The percentage of households that have the highest satisfactory level $(61-80 \%)$ is $18.5 \%, 48.6 \%$ are in the category of $41-60 \%$ satisfactory level and 
only $9.8 \%$ are not very comfortable with their metering system, with $5-20 \%$ satisfactory (Table 2).

The quantity of water calculated using the survey report is $12.75 \mathrm{~m}^{3} /$ month (average of 85litres/capital/day (lcpd)) for households of 5 people. The average of $85 \mathrm{lcpd}$ is lower than the WHO recommended quantity of $100 \mathrm{lcpd}$ but higher than the World Bank recommended values of 80lcpd for developing nations such as Nigeria[17]. A lot of factors contribute to water need among which are education, social status, climate, plumbing facilities and sewerage system[18].

The quantity of water supplied to each household by the Water-works is averagely $27 \mathrm{~m}^{3} /$ month. This is equivalent to $180 \mathrm{lcpd}$ for household of 5 people. The cost of producing $1 \mathrm{~m}^{3}$ of water is $\$ 569$ (Table 3), thus, for every $27 \mathrm{~m}^{3} /$ month supplied to each household, the total cost is $\$ 15,363 /$ month. The government charged $¥ 100 / \mathrm{m}^{3}$, so, households are charged $\$ 2700$ for metered users and $\$ 2000$ for unmetered users. The billing is low compared to the cost of treatment and production of $1 \mathrm{~m}^{3}$ water. When compared to the billing system in Lagos State, it is also considerably fair [11]. However, the percentage of people that receive water every day is low; most consumers believe the billing system is biased, thus, the willingness to pay is low and this agrees with most studies where metering is done in Nigeria [11].

Table 1:Percentage of metered and unmetered households

\begin{tabular}{ccc}
\hline $\begin{array}{c}\text { Use of water } \\
\text { meters }\end{array}$ & $\begin{array}{c}\text { Frequency } \\
\text { (persons) }\end{array}$ & Percentage \\
\hline Yes & 87 & 50.3 \\
No & 86 & 49.7 \\
\hline
\end{tabular}

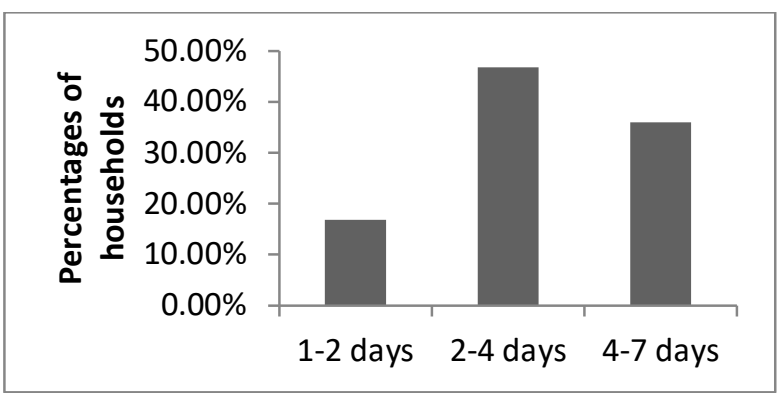

Figure 4: Percentages of households and numbers of days these households receive water

Table 2: Level of satisfaction with metering/billing method of the respondents

\begin{tabular}{ccc}
\hline $\begin{array}{c}\text { Level of satisfaction } \\
(\mathbf{\%})\end{array}$ & Frequency & Percentage \\
\hline $\mathbf{5 - 2 0}$ & 17 & 9.8 \\
$\mathbf{2 1 - 4 0}$ & 40 & 23.1 \\
$\mathbf{4 1 - 6 0}$ & 84 & 48.6 \\
$\mathbf{6 1 - 8 0}$ & 32 & 18.5 \\
Total & 173 & 100 \\
\hline Source [18] & &
\end{tabular}

Source [18]

Table 3: Data of water supply and billing

\begin{tabular}{|c|c|}
\hline $\begin{array}{l}\text { Number of households getting water } \\
\text { from Ede water works }\end{array}$ & $=378022$ \\
\hline Quantity of water produced per day & $=48220 \mathrm{~m}^{3}$ \\
\hline Cost of production of $1 \mathrm{~m}^{3}$ of water & $\begin{array}{l}=\$ 569 \\
=\cong 100\end{array}$ \\
\hline $\begin{array}{l}\text { Amount charged per } 1 \mathrm{~m}^{3} \text { (on metered } \\
\text { billing) }\end{array}$ & \\
\hline $\begin{array}{l}\text { Amount charged per month per } \\
\text { household for unmetered billing }\end{array}$ & 3220 \\
\hline Metered households & $27 \mathrm{~m}^{3}$ \\
\hline $\begin{array}{l}\text { Quantity of water supplied to } \\
\text { households/day }\end{array}$ & \\
\hline
\end{tabular}

\section{Conclusion}

The study showed that Ede Water Works supplies water to 378,022 households and only have metering system for $3222(0.85 \%)$ in Osogbo. The current households in Osogbo being supplied water by the water works are metered and billed $100 / \mathrm{m}^{3}$. 
Table 4: Calculated cost analysis of water supply

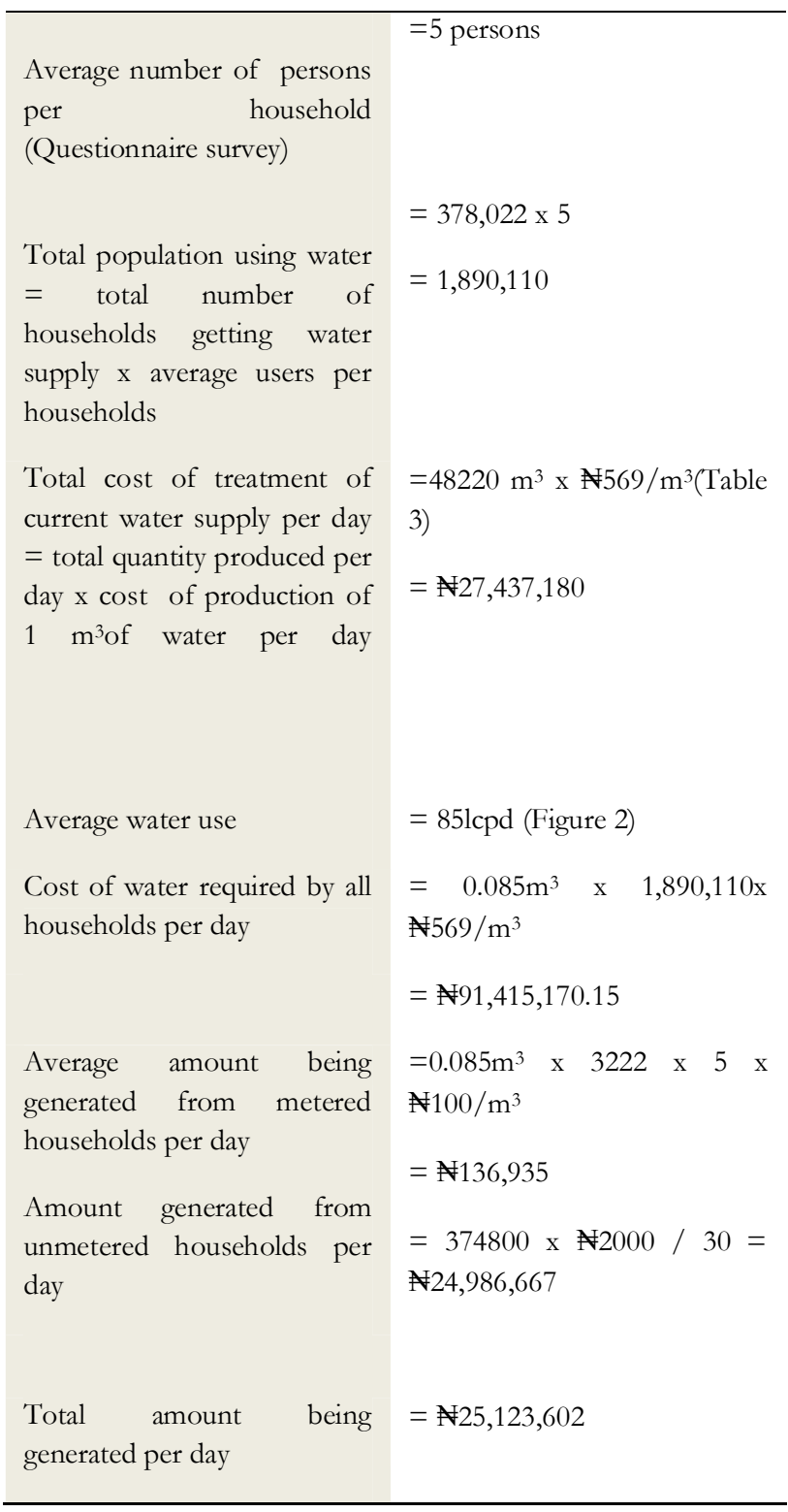

A larger percentage of the households are averagely satisfied with the billing system but are not comfortable for the interrupted water supply. Residents are encouraged to subscribe to the metering system for fair bargaining and good value for their money.

\section{References}

[1] Gbadegeshin, N. and Olorunfemi F. "Assessment of Rural Water Supply Management in Selected Rural Areas of Oyo State", African Technology Policy Studies (ATPS) Working Paper Series, no. 49, 2007.
[2] Bartram, J. and Cairncross, S. "Hygiene, Sanitation and Water", Forgotten Foundations of Health, PLoS Medicine, vol. 7, no. 11, 2010, pp. 1-9. [3] Biswas, A.K. "Integrated Water Resources Management", International Journal of Water Resources Development, vol. 24, 2008, pp. 5-22.

[4] Huttly, S.R.A., Blum, D., Kirkwood, B.R., Emeh, R.N., Okeke, N., Ajala, M. and Feachem, R.G. "The Imo State (Nigeria) Drinking Water Supply and Sanitation Project 2, Impact on Dracunculiasis, Diarrhea and Nutritional Status", Transactions of the Royal Society of Tropical Medicine and Hygiene, vol. 84, 1990, pp. 316-321.

[5] McDonald, R.I., Weber, K., Padowski, J., Flörke, M., Schneider, C., Green, P.A. and Montgomery, M. "Water on an Urban Planet: Urbanization and the Reach of Urban Water Infrastructure", Global Environmental Change, vol. 27, 2014, pp. 96-105.

[6] Saravanan, V.S. and Gondhalekar, D. "Water Supply and Sanitation as a 'Preventive Medicine': Challenges in Rapidly Growing Economies", Water International, vol. 38, 2013, pp. 867- 874 .

[7] WHO/UNICEF JMP. Progress on Drinking-water and Sanitation, http://www.wssinfo.org/fileadmin/user_upload/r esources/JMP-Update-report Accessed on 24th March 2015.

[8] Getis, A., Getis, J. and Fellmann, J.D. "Introduction to Geography", McGraw-Hill, New York, 11th Ed, 2008.

[9] Nwankwoala, H.O. "The Role of Communities in Improved Rural Water Supply systems in Nigeria: Management Model and its Implications for Vision 20:2020", Journal of Applied Technology in Environmental Sanitation, vol. 1, no. 3, 2011, pp. 295-302.

[10] Obeta, M.C. and Chukwu, K.E. "Water Supply and Demand in Nigeria, In: Anyadike, R.N.C., Obeta, M.C. (Eds), Water Resources Development and Management in Nigeria", Merit International Publication, Lagos, Nigeria, 2013, pp. 15564.

[11] www.pmnewsnigeria.com, Accessed on September 2, 2020

[12] Adesoji, D.J. "Significance of House-type as a Determinant of Residential Quality in Osogbo, 
Southwest Nigeria", Frontiers of Architectural, vol. 3, 2014, pp. 20-27.

[13] Ayanshola, A.M., Sule, B.F. and Salami, A. "Evaluation of Willingness to Pay for Reliable and Sustainable Household Water use in Ilorin, Nigeria", Ethiopian Journal of Environmental Studies and Management, vol. 6, 2013, pp. 754-762.

[14] Lu, T. and Smout, I. "Domestic Water Consumption: A Field Study in Harbin, China. WEDC International Conference, Ghana, 2008, pp. $1-4$.

[15] Ezenwaji, E.E., Eduputa, B.M. and Okoye, C.O. "Investigations into the Residential Water Demand and Supply in Enugu Metropolitan Area. Nigeria", American Joumal of Water Resources, vol. 4, 2016, pp. 22-29.

[16] Martins, O. "Water Resources Management and Development in Nigeria-Issues and Challenges in a New Millennium", An inaugural lecture delivered at the University of Agriculture, Abeokuta, Nigeria, https://www.unaab.edu.ng/attachments, Accessed on August 22, 2001.

[17] Ogedengbe M.O. "Environmental Engineering I (CVE 501) Lecture Note", Obafemi Awolowo University, Ile-Ife, 2001.

[18] Fadipe O.O. "Water and Environmental Engineering (CVE 415) Lecture Notes", Osun State University, Osogbo, 2020.

[19] OSWC, Osun State Water Corporation, Osun State, Nigeria, 2017. 